\title{
KONSEKUENSI MARRIED BY ACCIDENT DALAM PERSPEKTIF HUKUM POSITIF DAN HUKUM ISLAM
}

\author{
Imawanto ${ }^{1}$ \\ Dosen Fakultas Hukum Universitas Muhammadiyah Mataram \\ Email: Imawanto123@gmail.com \\ Edi Yanto ${ }^{2}$ \\ Dosen Fakultas Hukum Universitas Muhammadiyah Mataram \\ Email:Edidinata85@gmail.com \\ Mappanyompa ${ }^{3}$ \\ Dosen Fakultas Hukum Universitas Muhammadiyah Mataram \\ Email: Myompakaltim@gmail.com \\ DOI:https://doi.org/10.31764/jmk.v9i2.890
}

Received: Augst 1, 2018, Accepted: Sept 1, 2018 / Published: Oktober 30, 2018

\begin{abstract}
Abstrak
This article discusses married by accident, which is a marriage that is forced to be carried out between a pair of men and women because the woman is already pregnant, their parents must marry her, in order to cover up their disgrace in the community. Using juridical-normative research methods. The results of the study are, first, the law of being married by accident is permitted both by positive law and Islamic law, secondly, the position of a married by accident child becomes a legitimate child in the perspective of positive law, and an illegitimate child in the perspective of Islamic law. Third, in a positive legal perspective, the legal guardianship and inheritance rights of a daughter from married by accident are her biological father and inheritance rights from her parents, whereas in Islamic legal perspective the child resulting from married by accident biological father has no right to give heirs and is not entitled also becomes the child's guardian when married.
\end{abstract}

keywords: Islamic law; married by accident; positive law.

\begin{abstract}
Abstrak
Artikel ini membahas tentang married by accident, yaitu pernikahan yang terpaksa dilakukan antara sepasang laki-laki dan perempuan karena perempuannya sudah hamil terlebih dahulu, orang tua mereka harus menikahkannya, dalam rangka menutupi aib mereka di masyarakat. Menggunakan metode penelitian yuridis-normatif. Hasil penelitian, pertama, hukumnya married by accident di bolehkan baik oleh hukum positif dan hukum Islam, kedua, kedudukan anak married by accident menjadi anak sah dalam perspektrif hukum positif, dan anak tidak sah dalam perspektif hukum Islam. Ketiga, dalam perspektif hukum positif, hak wali dan hak waris anak perempuan dari married by accident adalah ayah biologisnya dan memperoleh hak waris dari kedua orang tuanya, sedangkan dalam perspektif hukum Islam anak hasil dari married by
\end{abstract}


accident ayah biologis tidak berhak memberikan waris dan tidak berhak pula menjadi wali anak tersebut ketika menikah.

kata kunci: hukum Islam; hukum positif; married by accident.

\section{PENDAHULUAN}

Masalah married by accident ini sudah sangat popular, baik terjadi dikalangan remaja kota maupun desa. Hal ini karena kasus-kasus hamil di luar nikah telah menjadi sesuatu yang sangat marak dan biasa terjadi di masyarakat. Dan kebiasaan yang berlaku dilingkungan masyarakat adat, baik patrilineal (suku Nias) maupun matrilineal (Minangkabau), dan belateral (Jawa), kalau terjadi perempuan hamil di luar nikah biasanya langsung di nikahkan, untuk menutupi aib. Rupanya pandangan adat tersebut di atas yang diambil untuk merumuskan Undang-Undang Nomor1 tahun 1974 tentang perkawinan dan KHI (Inpres Nomor 1 tahun 1991 tentang Kompilasi Hukum Islam.

Dalam konsep Islam akad nikah merupakan tonggak pemisah antara yang haram dan yang halal. Jadi yang di lihat adalah kapan dibenihkan anak tersebut bukan kapan dilahirkan anak tersebut. Berbeda dengan hukum positif yang dilihat adalah kapan anak tersebut di lahirkan, bukan kapan anak tersebut dibenihkan, dengan kata lain, biarkan sekarang menikah dan kemudian besok melahirkan maka status anak tersebut dalam persektif hukum positif, maka anak tersebut anak sah.

Karena dalam hukum Islam nasab hanya bisa dibentuk dengan perkawinan, bukan perzinaan atau yang lainnya. ${ }^{1}$ Sabda Nabi Salllallahu'alaihi wasallam, "nasab itu dari perkawinan yg sah, sedangkan bagi pezina adalah batu rajam"(HR Muslim). Hadist Nabi dari Abu Abdillah AnNu'man bin Basyir RA. Ia berkata, "Aku mendengar Nabi bersabda",

\footnotetext{
${ }^{1}$ Irfan Nurul, Nasab \& Status Anak dalam Hukum Islam, Jakarta: AMZAH, 2012.
} 
sesungguhnya yang halal itu jelas dan yang haram itu jelas, dan diantara keduanya ada perkara yang samar-samar, kebanyakan manusia tidak mengetahuinya, maka barang siapa menjaga dirinya dari yang samar-samar itu, berarti ia telah menyelamatkan agama dan kehormatannya, dan barang siapa terjerumus dalam wilayah samar-samar maka ia telah terjerumus kedalam wilayah yang haram,...(HR Bukhari Muslim). Maksudnya kita tidak boleh mengkompromikan antara yang halal dan haram. Maka dari itu, peneliti mencoba mengangkat menganalisis permasalahan ini.

\section{METODOLOGI}

Pada penelitian ini, menggunakan metode penelitian yuridis- normatif. Dalam penelitian ini digunakan penelitian hukum normatif, yaitu penelitian yang dilakukan terhadap asas-asas hukum, kaedah-kaedah hukum dalam arti nilai (norm), peraturan hukum konkrit dan sistem hukum, baik hukum positif dan hukum Islam. ${ }^{2}$

\section{PEMBAHASAN}

\section{A. Definisi Married By Accident}

Secara harfiah kata married by Accident terdiri dari 3 (tiga) kata, yaitu married, by dan accident. Married adalah kata kerja pasif dari marry yg artinya kawin atau nikah. By artinya karena/dengan, merupakan kata keterangan. Dan accident artinya sebuah kejadian yg mengejutkan atau kecelakaan. Married by accident adalah nikah karena kehamilan telah terlanjur terjadi yg pada umumnya tidak direncanakan oleh salah seorang atau kedua pasangan yg mengalaminya.

Dalam perspektif hukum Islam, perempuan hamil dibedakan menjadi dua keadaan. Pertama, perempuan yang dicearaikan suaminya dalam keadaan hamil, baik cerai hidup maupun cerai mati. Kedua,

\footnotetext{
2 Sudikno Mertokusumo, Penemuan Hukum, Liberty, Yogyakarta, 2004, hlm. 29.
} 
perempuan yang hamilakibat melakukan zina. Dan yang akan di bahas dalam jurnal ini adalah hukum perempuan yang hamil di luar nikah kemudian mereka melangsungkan pernikahan (married by accident).

\section{Hukum Married By Accident}

Para ulama berbeda pendapat di dalam masalah hukum married by accident, yaitu:

a) Imam Malik, Imam Ahmad, adalah tidak boleh menikahi perempuan yg sedang hamil karena berzina, kecuali setelah melahirkan. Berdasarkan:

(1) Hadist Nabi dari Abu Said Al-Khudri RA. "Jangan dipergauli perempuan hamil sampai ia melahirkan dan jangan pula yg tidak hamil sampai ia telah haid satu kali.

(2) Firman Allah “Dan perempuan-perempuan yg hamil waktu iddah mereka sampai melahirkan kandungannya". (QS Attolaq ayat4)

(3) Firman Allah "Dan wanita-wanita yang dithalaq hendaknya mereka menahan diri (menunggu) selama 3 kali suci (haid)" (QS AlBaqoroh ayat 228)

b) Imam Syafi'I dan Imam Abu Hanifah, berpendapat bahwa wanita yg sedang hamil karena berzina boleh dinikahkan tanpa harus terlebih dahulu menunggu melahirkan.

Selanjutnya Imam membolehkan nikah dan melakukan setubuh, baik yg menikahi laki-laki yg menzinai atau bukan. Imam Abu Hanifah, jika yg menikahi itu laki yang menzinai maka boleh setubuh, dan jika yg menikahi itu laki-laki lain, maka tidak boleh setubuh, harus menunggu melahirkan dan satu kali suci. Imam Syafi'I dan Imam as-Tsauri berpendapat bahwa tidak ada masa iddah bagi perempuan hamil karena berzina. Alasannya karena perbuatan dosa dan haram seperti perbuatan zina tidak akan di 
I'tirof (diakui), jadi menikahi perempuan hamil karena zina tidak ada larangan.

c) PERSIS (Persatuan Islam Indonesia): mengatakan bahwa perempuan hamil haram nikah dengan laki-laki yang menghamilinya atau dengan laki-laki lain, sampai ia melahirkan. ${ }^{3}$

d) MUHAMMADIYAH: boleh menikahi perempuan yang hamil karena zina oleh laki-laki yang menzinai, dan boleh juga menggauli/bersetubuh setelah nikah. ${ }^{4}$

Dalam Al-qur'an ditegaskan beberapa keadaan massa iddah perempuan, sehingga diharamkan menikahinya, yaitu:

1) Massa iddah yg dicerai hidup suaminya, jika perempuan itu tidak hamil, maka iddahnya 3 bulan 10 hari atau (100) hari.

Berdasarkan Firman Allah yang artinya: “Wanita-wanita yang ditalak handaklah menahan diri (menunggu) tiga kali quru'. Tidak boleh mereka menyembunyikan apa yang diciptakan Allah dalam rahimnya, jika mereka beriman kepada Allah dan hari akhirat. dan suami-suaminya berhak merujukinya dalam masa menanti itu, jika mereka (para suami) menghendaki ishlah. Dan para wanita mempunyai hak yang seimbang dengan kewajibannya menurut cara yang ma'ruf. Akan tetapi para suami, mempunyai satu tingkatan kelebihan daripada isterinya. Dan Allah Maha Perkasa lagi Maha Bijaksana. (QS. Al-Baqoroh ayat 228)

2) Masa iddah perempuan yg dicerai mati oleh suaminya, maka iddah mereka 4 bulan 10 hari atau 130 hari.

Berdasarkan firman Allah: "Orang-orang yang meninggal dunia di antaramu dengan meninggalkan isteri-isteri (hendaklah para isteri itu) menangguhkan dirinya (ber'iddah) empat bulan sepuluh hari. Kemudian apabila Telah habis 'iddahnya, Maka tiada dosa bagimu (para wali)

${ }^{3}$ Lihat hasil Istinbat dewan Hisbah PERSIS yang di nukil oleh H. Uyun Kamaluddin, 2006, menyorot ijtihad PERSIS, penerbit Tafakur, Bandung, Hal. 97)

4 Fatwa-Fatwa Tarjih “Tanya Jawab Agama 5” 2012, Hal. 148. 
membiarkan mereka berbuat terhadap diri mereka menurut yang patut. Allah mengetahui apa yang kamu perbuat" QS Al-Baqoroh ayat 234)

3) Masa iddah perempuan monopause, masa iddahnya adalah 3 bulan atau 90 hari.

Berdasarkan firman Allah "Dan perempuan-perempuan yang tidak haid lagi (monopause) di antara perempuan-perempuanmu jika kamu ragu-ragu (tentang masa iddahnya), Maka masa iddah mereka adalah tiga bulan; dan begitu (pula) perempuan-perempuan yang tidak haid.dan perempuan-perempuan yang hamil, waktu iddah mereka itu ialah sampai mereka melahirkan kandungannya. Dan barang -siapa yang bertakwa kepada Allah, niscaya Allah menjadikan baginya kemudahan dalam urusannya". (QS At-tholaq ayat 4).

4) Masa iddah perempuan hamil, adalah ia sampai melahirkan.

Berdasarkan firman Allah "....dan perempuan-perempuan yang hamil, waktu iddah mereka itu ialah sampai mereka melahirkan kandungannya. Dan barang siapa yang bertakwa kepada Allah, niscaya Allah menjadikan baginya kemudahan dalam urusannya".(QS At-tholaq ayat 4). Undang-Undang Nomor 1 Tahun 1974 tentang perkawinan tidak mengatur married by accident, karena Undang-Undang ini berlaku untuk seluruh bangsa Indonesia yg bersifat majemuk dan pluralistik terutama dari aspek kepercayaan dan agama. Di dalam Pasal 53 Kompilasi Hukum Islam mengatur tentang married by accident, yaitu sebagai berikut:

1) Seorang wanita hamil diluar nikah, dapat dikawinkan dengan pria yg mengahamilinya;

2) Perkawinan dengan wanita hamil yg disebut pada ayat 1 dapat dilangsungkan tanpa menunggu lebih dahulu kelahiran anaknya;

3) Dengan dilangsungkan perkawinan pada saat wanita hamil, tidak diperlukan perkawinan ulang setelah anak yg dikandung lahir.

Ada tiga (3) alasan yg dirasa konkordan sehingga perumus

Kompilasi Hukum Islam merumuskan P 53, yaitu berdasarkan: pertama, 
Firman Allah: "Laki-laki yang berzina tidak mengawini melainkan perempuan yang berzina, atau perempuan yang musyrik; dan perempuan yang berzina tidak dikawini melainkan oleh laki-laki yang berzina atau laki-laki musyrik, dan yang demikian itu diharamkan atas oran- orang yang mukmin". QS Annur ayat 3). Kedua, Menggunakan pendapat Imam Syafi'I dan Imam Hanafi, yg menyatakan kebolehan melaksanakan pernikahan dengan wanita hamil karena zina tanpa harus menunggu perempuan itu melahirkan. Meskipun pendapat di tersebut secara eksplisit bertentangan dengan Firman Allah yang artinya: “..dan perempuanperempuan yang hamil, waktu iddah mereka itu ialah sampai mereka melahirkan kandungannya..". (QS At- tholaq ayat 4). Pendapat Imam Syafi'I dan Hanafi tersebut, nampaknya lebih melihat teks/siakul kalam ayat tersebut dari ayat-ayat sebelumnya. Rangkaian ayat-ayat sebelumnya tidak membicarakan perempuan hamil karena zina, oleh karena itu sangat logis apabila kemudian Imam syafi'I berpendapat bahwa perempuan hamil karena zina tidak mempunyai masa iddah. Ketiga, melihat kultur atau kearifan lokal yang terdapat dibeberapa daerah masyarakat adat indonesesia bahwa jika seoarang perempuan hamil karena zina, maka segera dikawinkan dengan laki-laki yang mengahamilinya untuk menutup malu keluarga dan masyarakat desa bersangkutan.

\section{B. Kedudukan Anak Married by Accident}

Terhadap hal ini paling tidak terdapat tiga (3) pendapat yang berkembang, yaitu: 5

1. Pendapat ini mengatakan bahwa anak yang lahir dari perkawinan hamil diluar nikah tetap dipandang sebagai anak zina. Karena anak tersebut dibenihkan sebelum akad nikah (mitsaqon gholidhon). Dan

5 Anshary M. H., Kedudukan Anak dalam perspektif Hukum Hukum Islam dan Hukum Nasional. Bandung: Redaksi Mandar Maju, 2014. 
inilah pendapat yang paling benar berdasarkan syariat Islam/hukum Islam.

2. Pendapat ini mengatakan bahwa anak tersebut kedudukannya adalah anak sah. Karena pendapat ini mengikuti UndangUndang Nomor 1 tahun 1974 tentang perkawinan dan pasal 99 ayat (1) Kompilasi Hukum Islam, yang menyatakan "anak sah adalah anak yg dilahirkan dalam perkawinan yang sah". Dengan tujuan melindungi dan memberikan kepastian hukum kepada anak yang lahir nanti.

3. Pendapat ini mengatakan, jika anak lahir enam bulan setelah akad nikah, berarti usia kandungan sekitar bulan saat menikah, maka si anak otomatis sah dinasabkan pada ayahnya tanpa harus ada ikrar tersendiri. Namun jika si anak lahir sebelum enam bulan setelah pernikahan ortunya, berarti usia kandungan lebih 3 bulan saat menikah, maka ayahnya dipandang perlu untuk ikrar.

\section{Wali Nikah Anak Luar Nikah}

Berdasarkan hadist Nabi Sallalahu'alaihi wasallam, "Anak hanya bisa bernasab dengan laki-laki yang memiliki ranjang yang sah, sedangkan pezina hanya mendapatkan batu rajam" (HR Bukhari no 6760 dan Muslim no 1457 dari Muhammad bin Ziyad). Berdasarkan hadist Nabi Sallalahu'alaihi wasallam, "Penguasa adalah wali nikah bagi perempuan yang tidak memiliki wali nikah" 6(HR Abu Daud no 2083 dan dinilai shahih oleh al Albani)".

Berdasarkan Kompilasi Hukum Islam (Inpres Nomor 1 tahun 1991 tentang kompilasi hukum Islam,menjadi anak sah, walaupun di benihkan diluar nikah tapi dilahirkan di dalam pernikahan, maka anak tersebut menjadi anak sah dan yang menjadi wali adalah laki-laki yang menikahi ibunya tersebut, dan bahkan anak tersebut bisa menjadi ahliwaris dan berhak mendapatkan warisan.

\footnotetext{
${ }^{6}$ HR Abu Daud no 2083 dan dinilai shahih oleh al Albani
} 


\section{SIMPULAN}

Menurut hukum positif dan hukum Islam bahwa pertama, perempuan yang hamil di luar nikah boleh melaksanakan pernikahan dengan laki-laki yang menghamilinya dan boleh melakukan hubungan seksual tanpa harus melahirkan kandungannya terlebih dahulu (KHI Pasal 53). Kedua, kedudukan hukum anak yang dilahirkan menjadi anak sah, dan kedua orang tuanya berhak memberikan harta warisan dan berhak menjadi wali nikahnya (KHI). Ketiga, menurut hukum Islam terhadap perempuan hamil juga membolehkan melangsungkan pernikahan walaupun anak tersebut belum dilahirkan, akan tetapi anak yang lahir nanti apabila anak tersebut perempuan ayah biologisnya tidak bisa menjadi wali nikahnya, dan tidak berhak mendapatkan waris dari ayah biologisnya. Keempat, dalam hal warisan dalam perspektif hukum positif, anak tersebut anak tersebut berhak mendapatkan warisan dari ayah biologisnya, sedangkan dalam perspektif Islam anak tersebut tidak mendapatkan warisan dari ayah biologisnya.

\section{DAFTAR PUSTAKA}

\section{Buku}

Anshary M. H., 2014, Kedudukan Anak dalam perspektif Hukum Hukum Islam dan Hukum Nasional. Redaksi Mandar Maju, Bandung.

Hasil Istinbat dewan Hisbah PERSIS yang di nukil oleh H. Uyun Kamaluddin, 2006, menyorot ijtihad PERSIS, penerbit Tafakur, Bandung.

Irfan Nurul, 2012, Nasab \& Status Anak dalam Hukum Islam, AMZAH, Jakarta.

Tim Tarjih Pimpinan Pusat Muhammadiyah, 2006, Fatwa-Fatwa Tarjih Tanya Jawab Agama 5, Suara Muhammadiyah, Yogyakarta.

Ghozali Rahman Abdul, 2014, Fiqih Munahakhat, Kencana Prenadamedia Group, Jakarta.

Mardani, 2016, Hukum Keluarga Islam di Indonesia, Kencana, Jakarta.

Summa Amin Muhammad, 2005, Hukum Keluarga Islam di Dunia Islam, PT. Raja Grafindo Persada, Jakarta.

Intruksi Presiden Nomor. 1 Tahun 1991 Tentang Kompilasi Hukum Islam (KHI). 